\title{
A snapshot of ocean acidification research
}

\author{
Sam Dupont $\cdot$ Hans-O Pörtner
}

Received: 10 June 2013/Accepted: 13 June 2013/Published online: 27 June 2013

(c) Springer-Verlag Berlin Heidelberg 2013

\begin{abstract}
This special issue compiles 37 manuscripts investigating the biological impacts and societal relevance of ocean acidification. It includes important considerations regarding experimental design, new methods and how ocean acidification science can contribute to society through education and socioeconomic assessment. Altogether, this special issue constitutes a snapshot of recent ocean acidification research. This paper aims at summarizing the key findings and highlights future challenges and research priorities.
\end{abstract}

Keywords Ocean acidification - Multiple stressors · Experimental approach $\cdot$ Future research

\section{Introduction}

The earth's oceans are becoming more acidic as they draw from the levels of carbon dioxide $\left(\mathrm{CO}_{2}\right)$ rising in the atmosphere. Since the industrial revolution, the acidity of the surface ocean increased by $30 \%$. An additional doubling to tripling in acidity may occur by 2100 as the oceans absorb more $\mathrm{CO}_{2}$ released by a growing human population.

Communicated by U. Sommer.

\section{S. Dupont $(\square)$}

Department of Biological and Environmental Sciences,

The Sven Lovén Centre for Marine Sciences, University of Gothenburg, Kristineberg, 45178 Fiskebäckskil, Sweden e-mail: sam.dupont@bioenv.gu.se

\section{H.-O. Pörtner $(\square)$}

Department of Integrative Ecophysiology, Alfred Wegener Institute for Polar and Marine Research, Am Handelshafen 12, 27570 Bremerhaven, Germany

e-mail: hans.poertner@awi.de
There is little doubt that ongoing ocean acidification and related changes in ocean carbonate chemistry will contribute to major changes in marine ecosystems, but we are only beginning to understand the mechanistic background, the diversity of sensitivities and the evolutionary consequences of its impacts.

When scientists first became aware of the anticipated scale of ocean acidification, most eyes turned to calcifying organisms. Pioneering research on biological impacts showed that coccolithophores grow finer shells and become malformed (Riebesell et al. 2000); corals survive and reproduce but cannot build skeletons (Fine and Tchernov 2007), threatening the sustenance of reefs and the ecosystems around them. Brittle stars that congregate in high densities on the Atlantic floor and provide habitat and food for fish could become extinct in decades, as their larvae die within days in ocean acidification conditions (Dupont et al. 2008). More recently, massive die-offs in wild oyster populations and hatcheries along the US west coast were attributed to the upwelling of acidic waters, exacerbated by ongoing ocean acidification, thereby providing a glimpse into the future (Barton et al. 2012).

It is now clear that acidification impacts not only calcification and thus calcifying species, but a variety of biological processes associated with growth, reproduction and survival (see Garrard et al. 2012 for review). But it came as a surprise that some marine calcifiers are resilient to ocean acidification. Large mussel beds thrive in the depths of Kiel Fjord in Germany, despite being washed by seasonal flow of $\mathrm{CO}_{2}$-rich waters (Thomsen et al. 2010). Some species, calcifying or not, have the capacity to adapt to such conditions, others do not. Establishing the biological impacts of ocean acidification is then more difficult due to a range of physiological and ecological trade-offs leading to a variety of organism responses. The new 
challenge of ocean acidification research is to address these trade-offs and understand why some species survive and others do not. This will take a new generation of experiments. It will also become important to examine over long timescales the response of whole ecosystems to acidification and other stressors such as temperature.

\section{Ocean acidification: a field in expansion}

Ocean acidification is a growing truly interdisciplinary field. This special issue on "ocean acidification" compiles 37 manuscripts ( 31 "original papers," 5 papers providing "review, concept and synthesis" and 1 focusing on "methods"). This was made possible through the contribution of 171 authors from 64 institutions and 22 different countries (Fig. 1).

However, some countries or even continents are left relatively unexplored. For example, no studies from this special issue were performed on the coasts of Africa despite its biological and socioeconomical vulnerability to future global changes. Future work should focus on these neglected regions to support the projection of future impacts and the development of local management strategies (Kelly et al. 2012).

\section{Experimental design}

The present selection of papers covers a range of experimental approaches used to investigate the impact of ocean acidification on marine species and ecosystems. To date, a vast majority of studies are laboratory-based perturbation experiments (e.g., $90 \%$ of the articles in this special issue). However, field studies taking advantage of natural gradients or $\mathrm{CO}_{2}$-rich environments (e.g., Johnson et al. 2011; Porzio et al. 2013) or large-scale field studies using mesocosms (e.g., Troedsson et al. 2012) can provide insights into the short- and long-term responses at ecosystem level.

Every living organism is part of an ecosystem, and any change in this delicate network can cascade from species to species. One of the key gaps in knowledge includes the impact of ocean acidification on ecological interactions and the underlying mechanisms (Pörtner and Farrell 2008). However, most experiments to date are still focusing on single species ( $83 \%$ of the articles in this special issue). Karlberg and Wulff (2012) studied the impact of ocean acidification on two bloom-forming cyanobacteria of the Baltic Proper, separately and together. Their results suggest that ocean acidification might be beneficial for the two species dominating the extensive summer blooms. However, the biovolume of each species was lower when grown together emphasizing the importance of studying interactions between species. Schoo et al. (2012) showed that the acclimation of food organisms (e.g., the algae Rhodomonas salina) to ocean acidification can negatively impact the grazers (e.g., the copepod Acartia tonsa). These two studies highlight the importance to include ecological interactions in future experimental designs.

The average duration of perturbation experiments in studies published in this special issue was $49 \pm 17$ days. It ranged from 3 days to 16 months, but $25 \%$ of the experiments were shorter than 1 week and $93 \%$ were shorter than 3 months. However, long-term responses must be captured, especially in organisms that live for decades in complex life cycles. For example, after 4 months, female urchins exposed to ocean acidification produced 5 times fewer eggs. But after 16 months, with enough time to acclimate to their new environment, adult urchins reproduced normally (Dupont et al. 2012).

Acidification develops on top of natural variability and in tandem with other human-driven environmental changes, including warming, eutrophication, hypoxia and
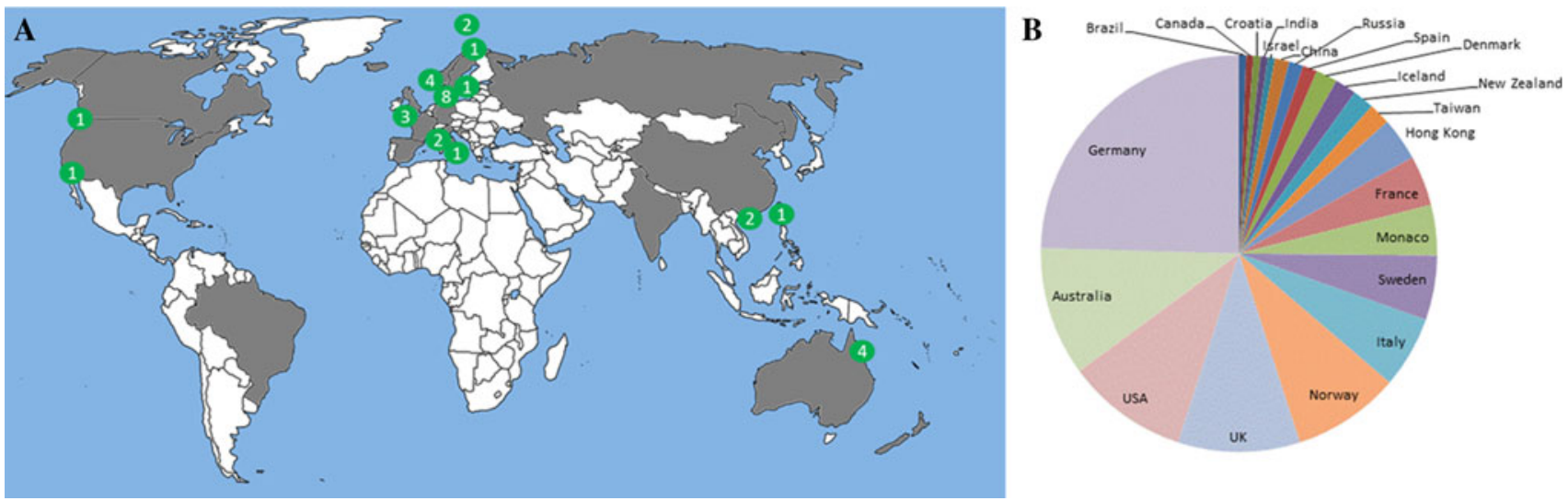

Fig. 1 a World map showing the origin of contributing institutions (countries in gray) and the number of articles per studied sites (green circles); $\mathbf{b}$ Contribution of each country to the special issue in relative number of authors 
pollution. Temperature is a key climate driver for biological changes, and ocean acidification modulates organism responses to temperature (Pörtner and Farrell 2008). For example, Arctic crabs exposed to temperature extremes reduce their activity, and this trend is exacerbated by ocean acidification (Zittier et al. 2012).

In this special issue, perturbation experiments included 2 to $12 \mathrm{pH}$ scenarios (average per study $3.8 \pm 0.4$; Fig. 2). One treatment was always considered as the control ("present," pH $8.08 \pm 0.01$ ), and other treatments were termed "near-future ocean acidification scenarios" with $\Delta \mathrm{pH}$ applied ranging from 0.06 to 2.1 . When several treatments were considered, the minimum $\Delta \mathrm{pH}$ applied per study ranged from 0.06 to 0.6 and the maximum $\Delta \mathrm{pH}$ ranged from 0.2 to 2.1 .

$\mathrm{pH}$ variation in coastal environments under ocean acidification is influenced by biotic parameters such as photosynthesis and respiration, which also vary depending on fluctuating abiotic and biotic factors. Seasonal changes in biological activities lead to highly variable $\mathrm{pH}$ values experienced by coastal organisms during the year on different spatiotemporal scales (e.g., Schulz and Riebesell 2012). As a consequence, atmospheric $p \mathrm{CO}_{2}$ is only one parameter to be considered when setting baseline treatment conditions and experimental design should rely on measurements of carbon chemistry in the actual habitat (McElhany and Busch 2012). A wide range of $\mathrm{pH}$ values should be tested to cover present and future environmental variability (e.g., more than 1 treatment should be considered as control and future treatments). At the same time, the impact of variability itself is also poorly understood.

Ocean acidification should also be considered in light of other environmental drivers, including warming, deoxygenation or pollutants on global, regional and local scales (e.g., Melzner et al. 2012; Schalkhausser et al. 2012). Schalkhausser et al. (2012) compared the response of the scallop Pecten maximus to ocean acidification at $4 \mathrm{C}$ (winter) and 10C (spring/summer). However, most studies exclusively considered ocean acidification (59\%; Fig. 3)

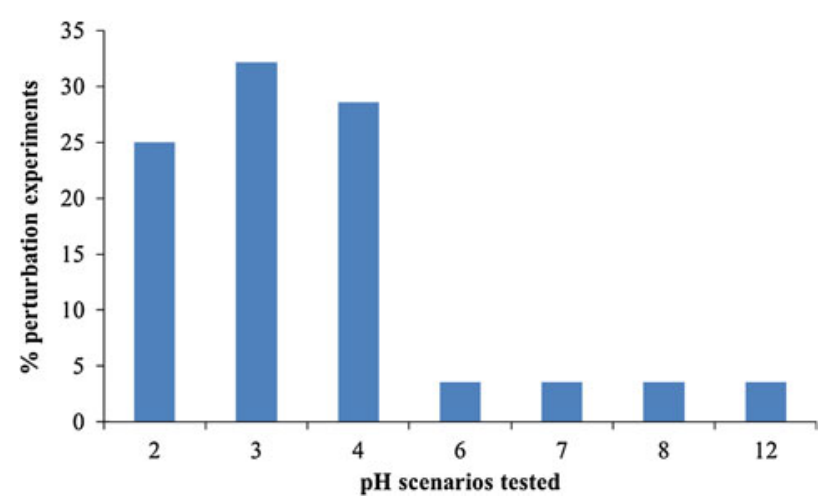

Fig. 2 Proportion of studies using different numbers of $\mathrm{pH}$ scenarios

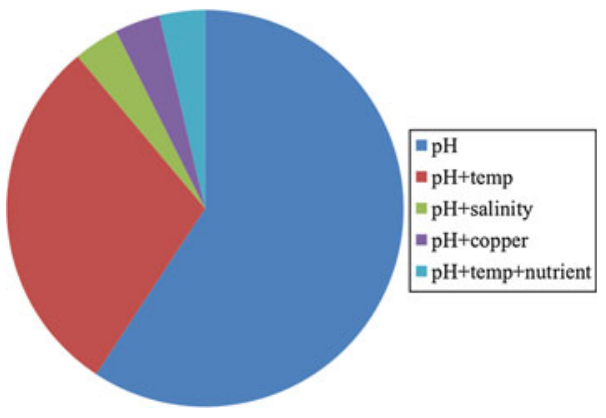

Fig. 3 Proportion of papers considering single $(\mathrm{pH})$ or multiple parameters

and only a few included 2 environmental parameters at a time: $37 \%$ combined $\mathrm{pH}$ and temperature; two studies combined pH and salinity (Karlberg and Wulff 2012; Lewis et al. 2012). Only one study considered 3 parameters ( $\mathrm{pH}$, temperature and nutrients; Troedsson et al. 2012). When a second parameter is considered, only 2 scenarios were considered for each parameter (with the exception of Hiebenthal et al. 2012 considering 5 treatments).

The interaction between environmental parameters is complex. For example, temperature was often the main driver of change (Arnberg et al. 2012; Hiebenthal et al. 2012; Karlberg and Wulff 2012) minimizing (e.g., Dorey et al. 2012) or amplifying the negative effect of $\mathrm{pH}$ (Schalkhausser et al. 2012), likely depending on where in the thermal window the control and experimental temperatures are set. Lewis et al. (2012) also demonstrated that $\mathrm{pH}$ increased the sensitivity to copper.

In the future, studies of ocean acidification should move away from "stamp collecting"-i.e., testing individual species in simplistic experimental conditions-to more complex experiment designs mimicking realistic environmental conditions and aiming at identifying unifying principles that would help us identify sensitive species and ecosystems. This requires long-term exposures and taking into account ecological interactions and relevant multiparameter environmental conditions (and their variability).

\section{Biological impacts}

Ocean acidification can lead to contrasting biological responses ranging from negative (e.g., increased mortality) to positive effects on fitness (e.g., the tunicate Oikopleura dioicai; Troedsson et al. 2012; Fig. 4).

This special issue compiles information on 26 species from 10 taxonomic groups [cyanobacteria (2 species), phytoplankton (1), macroalgae (2), annelids (2), corals (1), crustaceans (3), echinoderms (4), mollusks (7), tunicates (1), fish (3)]. These include the "usual suspects" in the field but also new or neglected taxonomic groups such as 


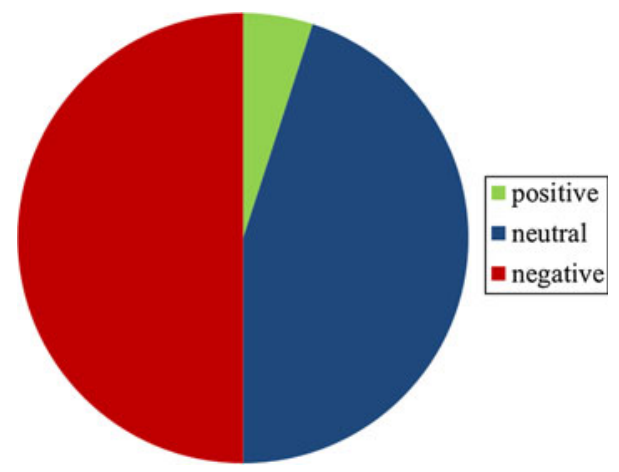

Fig. 4 Summary of impacts on fitness of species studied in this volume (relative number of species)
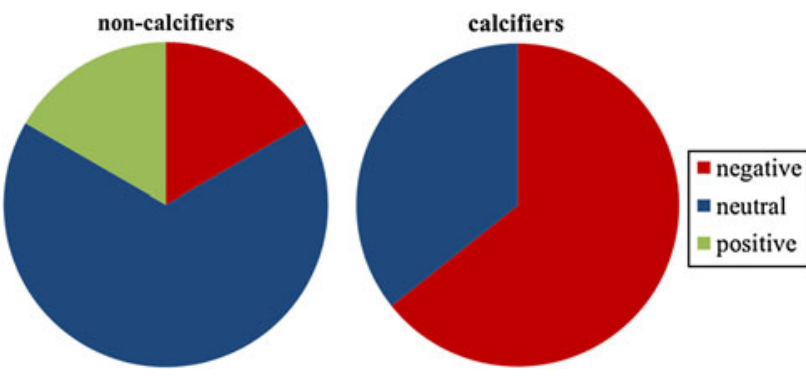

Fig. 5 Relative numbers of species studied showing negative (e.g., increased mortality), neutral or positive (e.g., increased reproduction and survival) impacts on fitness of both non-calcifiers and calcifiers

Annelids (Lane et al. 2012; Lewis et al. 2012) or Tunicates (Troedsson et al. 2012). Marine calcifiers (70\% of studied species) were on average more sensitive to ocean acidification than the non-calcifiers studied (Fig. 5).

Christen et al. (2012) confirmed that the impacts observed at species levels are mirrored in changes at ecosystem level. Working on intertidal macrobenthic communities, they showed that communities experienced significant changes in structure and reduced diversity in response to ocean acidification: shifting from a community dominated by calcareous organisms to one with lower abundances and diversity of mollusks and arthropods. Altogether, these results confirm that there will be "winners" and "losers" in response to ocean acidification with consequences at ecosystem level. These findings stress the importance of considering all taxonomical groups coexisting and interacting at ecosystem level.

\section{The importance of relevant end points}

The impact of ocean acidification bears consequences for human society. It then appears critical to include relevant end points (e.g., survival, growth) in any experimental design. This special issue is a nice illustration that new end points are now considered. "Classic" fitness-related parameters are included in $79 \%$ of the studies (e.g., $58 \%$ growth; $58 \%$ survival; $21 \%$ abnormality). Previously neglected but critical parameters such as fertility are also considered. For example, Uthicke et al. (2012) showed that short-term exposure to ocean acidification can impact male fertility negatively in sea urchins. Dupont et al. (2012) showed that female fertility is only reduced during medium-term exposures. It was also confirmed that transition phases such as fertilization can be negatively impacted (Gonzalez-Bernat et al. 2012; Lewis et al. 2012). In contrast, larval metamorphosis into juveniles remained unaffected in echinoderms and annelids (Dupont et al. 2012; Lane et al. 2012). Five studies showed that ocean acidification alone or in combination with temperature change can impact behavior in fish (Devine and Munday 2012; Munday et al. 2012, but see Maneja et al. 2012), mollusks (Schalkhausser et al. 2012) and crustaceans (Zittier et al. 2012).

What is needed to improve predictive power is a greater understanding of mechanisms in action. This will be possible through a better understanding of the biological responses at molecular and physiological levels. Several articles consider responses at the levels of the proteome (Dineshram et al. 2013) and the transcriptome (qPCR, Hüning et al. 2012; Putnam et al. 2012) revealing plasticity at the molecular level, the importance of post-translational processes (Dineshram et al. 2013) and identifying pathways that can be impacted. These were complemented by physiological studies in $45 \%$ of the published articles. Respiration (21\%) and calcification (21\%) were most frequently studied, but others were also considered including feeding (1 study), photosynthesis ( 2 studies) and acid-base regulation ( 1 study). These studies reported a range of responses. For example, it was shown that calcification can be strongly inhibited under ocean acidification (e.g., Lane et al. 2012; Fig. 6a), but can also be stimulated leading to hyper-calcification (e.g., Dorey et al. 2012). Bradassi et al. (2013) also shown that under ocean acidification, the maintenance of skeletal structure is possible through new trade-offs between calcification and dissolution (Fig. 6b).

\section{Life stages, proof of concepts and surprises}

Many benthic species have a complex life cycle including embryos/larvae, juveniles and adults. The field of ocean acidification is now at a stage of complementing the study of various life stages. Only a small number of articles consider more than 1 life-history stage. However, differential effects of ocean acidification on various life-history stages, including carry-over effects between consecutive life stages, with consequences for communities and 

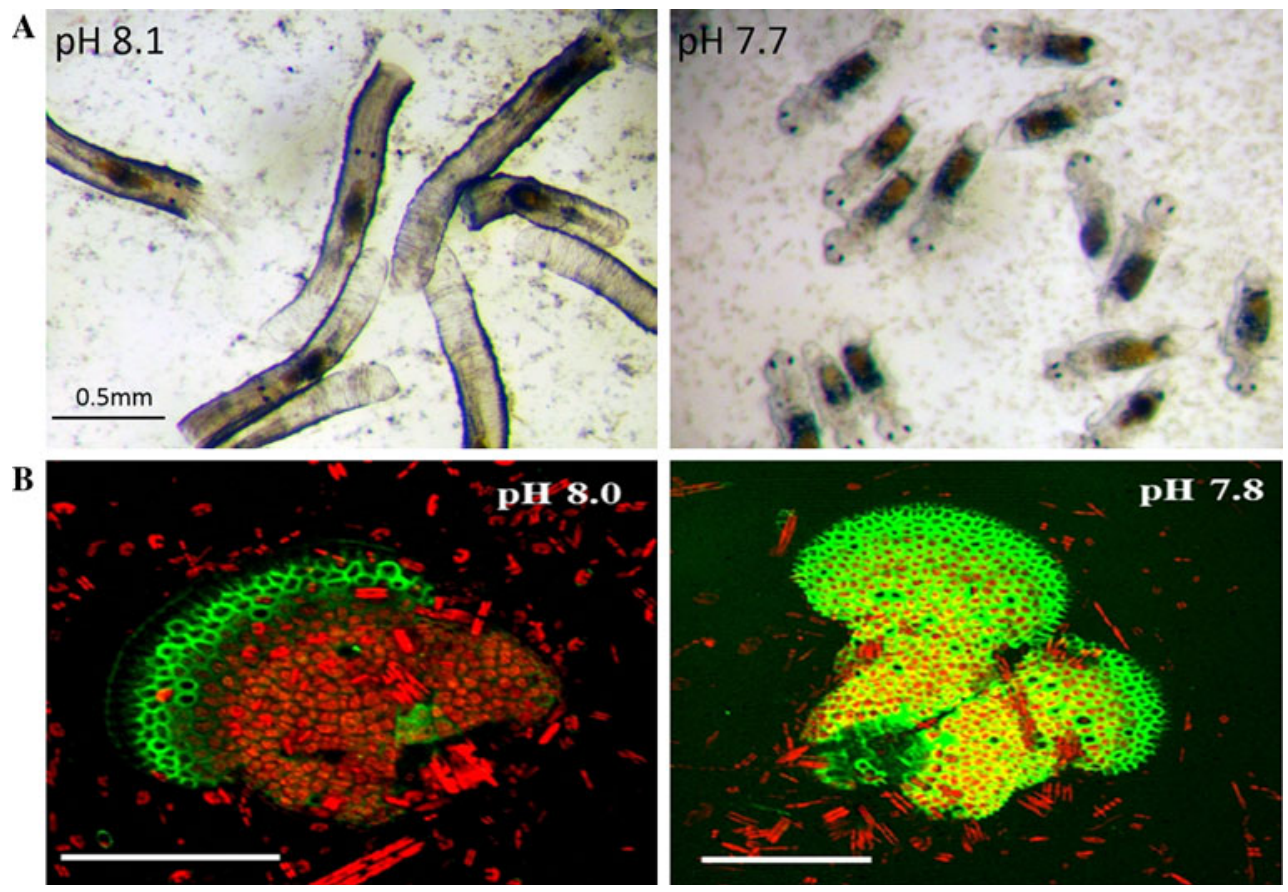

Fig. 6 Impact of ocean acidification on calcification. a Larval metamorphosis of the serpulid tubeworm, Hydroides elegans, at $\mathrm{pH}$ 8.1 and $\mathrm{pH}$ 7.7. Larvae were reared in varying $\mathrm{pH}$ conditions for 4 days before they attained competency and were induced to attach and metamorphose into juveniles by a natural multi-species microbial biofilm. Pictures were taken $24 \mathrm{~h}$ after the completion of metamorphosis. Tubeworm larvae were able to completely metamorphose, but unable to produce a calcified tube at $\mathrm{pH} 7.7$ (courtesy, Dr. Lane \&

ecological interactions demonstrated the importance to include the whole life cycle in future experimental design (larvae and juveniles: Dorey et al. 2012; Lane et al. 2012; adult-larvae: Uthicke et al. 2012; adult-larvae-juvenile: Dupont et al. 2012; the whole life cycle: Troedsson et al. 2012). For example, urchin larvae exposed to ocean acidification produced juveniles that were 10 times more sensitive to ocean acidification (Dupont et al. 2012).

This special issue also illustrates the fact that ocean acidification can lead to "unexpected" effects. As an example, Chan et al. (2012) showed that ocean acidification can induce larval budding in sea urchin larvae. There are more surprises to come, and there is still space for exploratory science.

As a consequence, the field is still widening the range of reported phenomena. In addition, existing knowledge has led to the formulation of relevant hypotheses, e.g., the role of acid-base regulation or reliance on calcified structures in shaping sensitivity, energy budget or behavior; the interaction between temperature, hypoxia and $\mathrm{CO}_{2}$; the potential role of epigenetics in carry-over effects; or the role of dynamic thermal niches in shaping species interactions (e.g., Pörtner and Farrell 2008; Melzner et al. 2009; Knoll and Fischer, 2011; Nilsson et al. 2012; Dupont et al. 2012;
Dr. Thiyagarajan). b Confocal image of calcein-labeled skeleton of crustose coralline alga Phymatolithon lenormandii grown at $\mathrm{pH} 8.0$ and $\mathrm{pH}$ 7.8. Newly formed skeleton during the exposure to calcein is labeled in green/yellow. Red labeling is the chlorophyll autofluorescence. At $\mathrm{pH}$ 8.0, only the growing margin of the thallus is labeled,

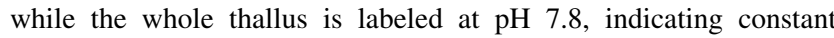
dissolution/calcification processes. Scale bar $=100 \mu \mathrm{m}$

Pörtner 2008, 2012). Accordingly, the field is moving toward more hypothesis-driven research and focusing on the proof of these and other concepts.

\section{Conclusions and perspectives}

What is needed overall is a greater understanding of physiological, evolutionary and ecological mechanisms. A single experiment would not allow capturing the level of complexity involved. Single-species perturbation experiments can elucidate its physiological responses to multiple environmental conditions and, in long-term studies over multiple generations, its evolutionary potential. Mesocosms can unravel the key role of ecological interactions. Monitoring combined with modeling can help understand the key role of natural variability in species responses. Investigations of species in a natural gradient of temperature and $\mathrm{CO}_{2}$ can also provide key information on the potential of organisms to acclimate and adapt. While manpower, funding and methodologies will always be limited when addressing specific research questions, there is one overarching limitation. There is a lack of idea of and approach to how the overarching principles of ocean 
acidification effects can be understood across organism domains. Such understanding will be a crucial basis for addressing questions at ecosystem level, e.g., in biogeochemical processes such as nitrogen fixation or the interactions between distantly related organisms such as animals, plants and bacteria.

Ocean acidification has already begun and can, alone or in combination with other stressors, have significant effects on marine ecosystems and their services to humankind. In light of the long-term perspective of ocean acidification and the millennia it will take to reverse the changes in ocean chemistry, we believe that rather than only documenting the disaster, research should also be oriented toward finding solutions. By improving our understanding of the biological impacts of ocean acidification, we will be able to identify the organisms and ecosystems more at risk that deserve our more urgent attention. While working on the cause of ocean acidification through a reduction in $\mathrm{CO}_{2}$ emissions (Fauville et al. 2012; Hilmi et al. 2012), we can buy some time by working on other factors decreasing ecosystem resilience such as over-fishing or pollution. We can also explore other solutions such as the optimization of aquaculture or the isolation of strains of important species resilient to ocean acidification. Many scientific challenges are ahead of us, but it is time to get ready for the future oceans.

Acknowledgments The authors are grateful to Dr. Barbara Santer, Prof. Ulrich Sommer and the editorial team of Marine Biology for their constant support. We also would like to thank all authors for their contribution to their special issue, patience and commitment during the editing process. SD is funded by the Linnaeus Centre for Marine Evolutionary Biology at the University of Gothenburg (http://www.cemeb.science.gu.se/) and supported by a Linnaeus grant from the Swedish Research Councils VR and Formas.

\section{References}

Arnberg M, Calosi P, Spicer JI, Tandberg AHS, Nilsen M, Westerlund S, Bechmann RK (2012) Elevated temperature elicits greater effects than decreased $\mathrm{pH}$ on the development, feeding and metabolism of northern shrimp (Pandalus borealis) larvae. Mar Biol (in this issue). doi:10.1007/s00227-012-2072-9

Barton A, Hales B, Waldbusser GG, Langdon C, Feely RA (2012) The Pacific oyster, Crassostrea gigas, shows negative correlation to naturally elevated carbon dioxide levels: implications for near-term ocean acidification effects. Limnol Oceanogr 57:698-710

Bradassi F, Cumani F, Bressan G, Dupont S (2013) Early reproductive stages in the crustose coralline alga Phymatolithon lenormandii are strongly affected by mild ocean acidification. Mar Biol (in this issue). doi:10.1007/s00227-013-2260-2

Chan KYK, Grünbaum D, Arnberg M, Thorndyke M, Dupont S (2012) Ocean acidification induces budding in larval sea urchins. Mar Biol (in this issue). doi:10.1007/s00227-012-2103-6

Christen N, Calosi P, McNeill CL, Widdicombe S (2012) Structural and functional vulnerability to elevated $p \mathrm{CO}_{2}$ in marine benthic communities. Mar Biol (in this issue). doi:10.1007/s00227012-2097-0
Devine BM, Munday PL (2012) Habitat preferences of coralassociated fishes are altered by short-term exposure to elevated $\mathrm{CO}_{2}$. Mar Biol (in this issue). doi:10.1007/s00227-012-2051-1

Dineshram R, Thiyagarajan V, Lane A, Ziniu Y, Xiao S, Leung PTY (2013) Elevated $\mathrm{CO}_{2}$ alters larval proteome and its phosphorylation status in the commercial oyster, Crassostrea hongkongensis. Mar Biol (in this issue). doi:10.1007/s00227-013-2176-X

Dorey N, Melzner F, Martin S, Oberhänsli F, Teyssié J-L, Bustamante P, Gattuso J-P, Lacoue-Labarthe T (2012) Ocean acidification and temperature rise: effects on calcification during early development of the cuttlefish Sepia officinalis. Mar Biol (in this issue). doi:10.1007/s00227-012-2059-6

Dupont S, Havenhand J, Thorndyke W, Peck L, Thorndyke M (2008) Near-future level of $\mathrm{CO}_{2}$-driven ocean acidification radically affects larval survival and development in the brittlestar Ophiothrix fragilis. Mar Ecol Prog Ser 373:285-294

Dupont S, Dorey N, Stumpp M, Melzner F, Thorndyke M (2012) Long-term and trans-life-cycle effects of exposure to ocean acidification in the green sea urchin Strongylocentrotus droebachiensis. Mar Biol (in this issue). doi:10.1007/s00227-0121921-x

Fauville G, Säljö R, Dupont S (2012) Impact of ocean acidification on marine ecosystems: educational challenges and innovations. Mar Biol (in this issue). doi:10.1007/s00227-012-1943-4

Fine M, Tchernov D (2007) Scleractinian Coral species survive and recover from decalcification. Science 315:1811

Garrard SL, Hunter RC, Frommel AY, Lane AC, Phillips JC, Cooper R, Dineshram R, Cardini U, McCoy SJ, Arnberg M, Rodriguez Alves BG, Annane S, de Orte MR, Kumar A, Aguirre-Martínez GV, Maneja RH, Basallote MD, Ape F, Tortensson A, Bjoerk MM (2012) Biological impacts of ocean acidification: a postgraduate perspective on research priorities. Mar Biol (in this issue). doi:10.1007/s00227-012-2033-3

Gonzalez-Bernat MJ, Lamare M, Uthicke S, Byrne M (2012) Fertilisation, embryogenesis and larval development in the tropical intertidal sand dollar Arachnoides placenta in response to reduced seawater $\mathrm{pH}$. Mar Biol (in this issue). doi: 10.1007/s00227-012-2034-2

Hiebenthal C, Philipp EER, Eisenhauer A, Wahl M (2012) Effects of seawater $p \mathrm{CO}_{2}$ and temperature on shell growth, shell stability, condition and cellular stress of Western Baltic Sea Mytilus edulis (L.) and Arctica islandica (L.). Mar Biol (in this issue). doi: 10.1007/s00227-012-2080-9

Hilmi N, Allemand D, Dupont S, Safa A, Haraldsson G, Nunes PALD, Moore C, Hattam C, Reynaud S, Hall-Spencer JM, Fine M, Turley C, Jeffree R, Orr J, Munday PL, Cooley SR (2012) Towards improved socio-economic assessments of ocean acidification's impacts. Mar Biol (in this issue). doi:10.1007/ s00227-012-2031-5

Hüning AK, Melzner F, Thomsen J, Gutowska MA, Krämer L, Frickenhaus, Rosenstiel P, Pörtner H-O, Philipp AER, Lucassen M (2012) Impacts of seawater acidification on mantle gene expression patterns of the Baltic Sea blue mussel: implications for shell formation and energy metabolism. Mar Biol (in this issue). doi:10.1007/s00227-012-1930-9

Johnson VR, Brownlee C, Rickaby REM, Graziano M, Milazzo M, Hall-Spencer JM (2011) Responses of marine benthic microalgae to elevated $\mathrm{CO}_{2}$. Mar Biol (in this issue). doi:10.1007/ s00227-011-1840-2

Karlberg M, Wulff A (2012) Impact of temperature and species interaction on filamentous cyanobacteria may be more important than salinity and increased $p \mathrm{CO}_{2}$ levels. Mar Biol (in this issue). doi:10.1007/s00227-012-2078-3

Kelly RP, Foley MM, Fisher WS, Feely RA, Halpern BS, Waldbusser GG, Caldwell MR (2012) Mitigating local causes of ocean acidification with existing laws. Science 332:1036-1037 
Knoll AH, Fischer WW (2011) Skeletons and ocean chemistry: the long view. In: Gattuso J-P, Hansson L (eds) Ocean acidification. Oxford University Press, Oxford

Lane AC, Mukherjee J, Chan VBS, Thiyagarajan V (2012) Decreased $\mathrm{pH}$ does not alter metamorphosis but compromises juvenile calcification of the tube worm Hydroides elegans. Mar Biol (in this issue). doi:10.1007/s00227-012-2056-9

Lewis C, Clemow K, Holt WV (2012) Metal contamination increases the sensitivity of larvae but not gametes to ocean acidification in the polychaete Pomatoceros lamarckii (Quatrefages). Mar Biol (in this issue). doi:10.1007/s00227-012-2081-8

Maneja RH, Frommel AY, Browman HI, Clemmesen C, Geffen AJ, Folkvord A, Piatkowski U, Durif CMF, Bjelland R, Skiftesvik AB (2012) The swimming kinematics of larval Atlantic cod, Gadus morhua L., are resilient to elevated seawater $p \mathrm{CO}_{2}$. Mar Biol (in this issue). doi:10.1007/s00227-012-2054-y

McElhany P, Busch DS (2012) Appropriate $p \mathrm{CO}_{2}$ treatments in ocean acidification experiments. Mar Biol (in this issue). doi: 10.1007/s00227-012-2052-0

Melzner F, Gutowska MA, Langenbuch M, Dupont S, Lucassen M, Thorndyke MC, Bleich M, Pörtner H-O (2009) Physiological basis for high $\mathrm{CO}_{2}$ tolerance in marine ectothermic animals: preadaptation through lifestyle and ontogeny? Biogeosciences 6:1-19

Melzner F, Thomsen J, Koeve W, Oschilies A, Gutowska MA, Bange HW, Hansen HP, Körtzinger A (2012) Future ocean acidification will be amplified by hypoxia in coastal habitats. Mar Biol (in this issue). doi:10.1007/s00227-012-1954-1

Munday PL, Pratchett MS, Dixson DL, Donelson JM, Endo GGK, Reynolds AD, Knuckey R (2012) Elevated $\mathrm{CO}_{2}$ affects the behavior of an ecologically and economically important coral reef fish. Mar Biol (in this issue). doi:10.1007/s00227012-2111-6

Nilsson GE, Dixson DL, Domenici P, McCormick MI, Sørensen C, Watson S-A, Munday PL (2012) Near-future carbon dioxide levels alter fish behaviour by interfering with neurotransmitter function. Nat Clim Chang 2:201-204

Pörtner HO (2008) Ecosystem effects of ocean acidification in times of ocean warming: a physiologist's view. Mar Ecol Progr Ser $373: 203-217$

Pörtner HO (2012) Integrating climate-related stressor effects on marine organisms: unifying principles linking molecule to ecosystem-level changes. Mar Ecol Prog Ser 470:273-290

Pörtner HO, Farrell AP (2008) Physiology and climate change. Science 322:690-692
Porzio L, Garrard SL, Buia MC (2013) The effect of ocean acidification on early algal colonization stages at natural $\mathrm{CO}_{2}$ vents. Mar Biol (in this issue). doi:10.1007/s00227-013-2251-3

Putnam HM, Mayfield AB, Fan TY, Chen CS, Gates RD (2012) The physiological and molecular responses of larvae from the reefbuilding coral Pocillopora damicornis exposed to near-future increases in temperature and $p \mathrm{CO}_{2}$. Mar Biol (in this issue). doi: 10.1007/s00227-012-2129-9

Riebesell U, Zondervan I, Rost B, Tortell PD, Zeebe RE, Morel FMM (2000) Reduced calcification of marine plankton in response to increased atmospheric $\mathrm{CO}_{2}$. Nature 407:364-367

Schalkhausser B, Bock C, Stemmer K, Brey T, Pörtner H-O, Lannig G (2012) Impact of ocean acidification on escape performance of the king scallop, Pecten maximus, from Norway. Mar Biol (in this issue). doi:10.1007/s00227-012-2057-8

Schoo KL, Malzhan AM, Krause E, Boersma M (2012) Increased carbon dioxide availability alters phytoplankton stoichiometry and affects carbon cycling and growth of a marine planktonic herbivore. Mar Biol (in this issue). doi:10.1007/s00227012-2121-4

Schulz KG, Riebesell U (2012) Diurnal changes in seawater carbonate chemistry speciation at increasing atmospheric carbon dioxide. Mar Biol (in this issue). doi:10.1007/s00227-0121965-y

Thomsen J, Gutowska MA, Saphörster J, Heinemann A, Trübenbach K, Fietzke J, Hiebenthal C, Eisenhauer A, Körtzinger A, Wahl M, Melzner F (2010) Calcifying invertebrates succeed in a naturally $\mathrm{CO}_{2}$-rich coastal habitat but are threatened by high levels of future acidification. Biogeosciences 7:3879-3891

Troedsson C, Bouquet J-M, Lobon CM, Novac A, Nejstgaard JC, Dupont S, Bosak S, Jacoksen HH, Romanova N, Pankoke LM, Isla A, Dutz J, Sazhin AF, Thompson EM (2012) Effects of ocean acidification, temperature and nutrient regimes on the appendicularian Oikopleura dioica: a mesocosm study. Mar Biol (in this issue). doi:10.1007/s00227-012-2137-9

Uthicke S, Soars N, Foo S, Byrne M (2012) Effects of elevated pCO2 and the effect of parent acclimation on development in the tropical Pacific sea urchin Echinometra mathaei. Mar Biol (in this issue). doi:10.1007/s00227-012-2023-5

Zittier ZMC, Hirse T, Pörtner H-O (2012) The synergistic effects of increasing temperature and $\mathrm{CO}_{2}$ levels on activity capacity and acid-base balance in the spider crab, Hyas araneus. Mar Biol (in this issue). doi:10.1007/s00227-012-2073-8 